\title{
9. GEOCHEMISTRY OF SECONDARY CARBONATES IN LEG 115 BASALTS: TRACERS OF BASALT/SEAWATER INTERACTION ${ }^{1}$
}

\author{
Stephen J. Burns, ${ }^{2,}{ }^{3}$ Peter K. Swart, ${ }^{2}$ and Paul A. Baker ${ }^{4}$
}

\begin{abstract}
This report presents the results of a study of the stable isotopic and chemical composition of secondary carbonate minerals precipitated within basalts at Ocean Drilling Program Sites 707 and 715 . At Site 715, the secondary carbonates are all composed of calcite and display a narrow range of carbon and oxygen stable isotope ratios, with values ranging from $-2.75 \%$ to $1.95 \%$ PDB and $-0.27 \%$ to $2.86 \%$ PDB, respectively. Strontium, iron, and manganese values of the samples are generally low. The geochemistry of Site 715 samples indicates that they precipitated from seawater-dominated fluids, at low temperatures, as is typical of secondary carbonates from most Deep Sea Drilling Project sites.

In contrast, at Site 707, aragonite, siderite, and manganese-rich calcite occur as secondary carbonates in addition to calcite. The carbon isotopes of the Site 707 carbonates of all rock types are depleted in ${ }^{13} \mathrm{C}$. Values range from $-2.79 \%$ to $-16.43 \%$ PDB. Oxygen isotope values do not show a wide variation, ranging from $-1.78 \%$ to $1.17 \%$. The strontium contents of the samples range from 5200 to $8100 \mathrm{ppm}$ for aragonites, and from 145 to $862 \mathrm{ppm}$ for calcites. Iron and manganese contents are high in calcites and siderites and low in aragonites. Site 707 carbonates precipitated at low temperatures in a fairly closed system, in which basalt-seawater interaction has greatly influenced the chemistry of the pore fluids. The reactions occurring within the system before and in conjunction with secondary carbonate precipitation include oxidation of isotopically light methane, derived from fluids circulating within the basalts, and reduction of substantial amounts of iron and manganese oxides from the basalts.
\end{abstract}

\section{INTRODUCTION}

Sites 707 and 715 of Ocean Drilling Program (ODP) Leg 115 were drilled in the northwest Indian Ocean on the northern portion of the Mascarene Plateau and the eastern margin of the Maldives Ridge, respectively (Fig. 1). At each site, drilling objectives included recovery of basaltic basement rocks. Approximately $70 \mathrm{~m}$ of basement was penetrated, with significant recovery, at each site (Backman, Duncan, et al., 1988). As outlined in more detail below, there are significant differences in the thickness, environment of extrusion, and alteration products of basalts from each of the two sites. At each, however, alteration of the basalts includes the precipitation of secondary carbonate minerals in vesicles and veins by hydrothermal fluids. The purpose of this study was to investigate the mineralogy, and the stable isotope, and trace element chemistry of the secondary carbonates to gain insight into the nature of the latest stages of basalt alteration at these two sites.

Our specific objectives included (1) determination of the controls on the mineralogical and chemical variation of secondary carbonates; (2) an investigation of the types of low-temperature chemical reactions that occurred at the two sites; and (3) determination of the formation temperatures of carbonate minerals.

\section{PREVIOUS WORK}

Previous investigations of the postdeuteric alteration products of oceanic basalts, clays, zeolites, and carbonates that fill fractures and vesicles have led to a good understanding of the products of low-temperature basalt alteration and their sequence of formation (Bass, 1976; Andrews, 1977; Boehlke, 1980); the

\footnotetext{
${ }^{1}$ Duncan, R. A., Backman, J., Peterson, L. C., et al., 1990. Proc. ODP, Sci. Results, 115: College Station, TX (Ocean Drilling Program).

2 Rosenstiel School of Marine and Atmospheric Science, 4600 Rickenbacker Causeway, Miami, FL 33149, U.S.A.

${ }^{3}$ Present address: Geologisches Institut, Baltzerstrasse 1, CH-3012, Bern, Switzerland.

${ }^{4}$ Department of Geology, Duke University, Durham, NC 22706, U.S.A.
}

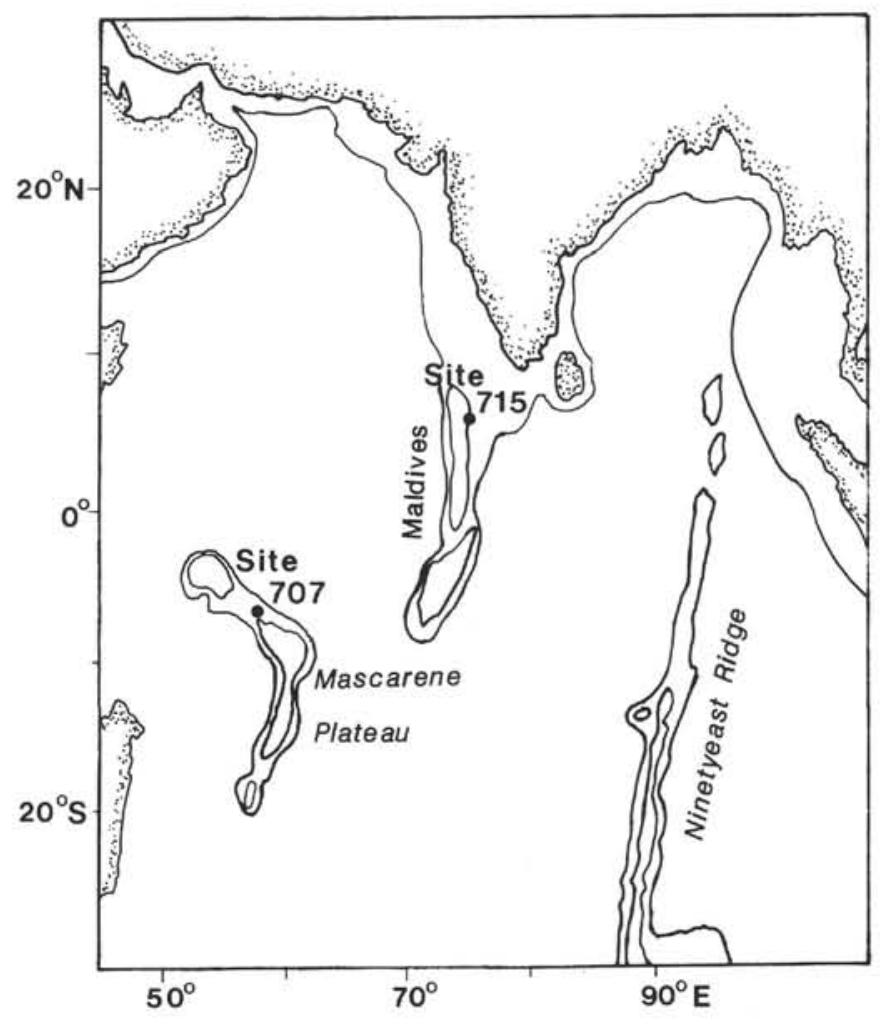

Figure 1. Location of Sites 707 and 715 in the northwest Indian Ocean.

timing and duration of formation of various mineral assemblages; and the chemical evolution of hydrothermal solutions (Hart and Staudigel, 1979; Staudigel et al., 1979, 1981a, 1981b).

In general, ocean crust alters in four distinct stages: (1) formation of palagonite, (2) formation of smectites, (3) formation of carbonates, and (4) dehydration (Staudigel et al., 1981a). 
During the first stage, basaltic glass is altered to palagonite, a poorly crystalline mineral of variable chemical composition that has been termed a proto-smectite/proto-celadonite. In the second stage, more crystalline smectites, zeolites (e.g., analcite), and micas (celadonite) are formed. During these two stages, the bulk of the chemical exchange between basalt and seawater probably occurs (Staudigel et al., 1981a, 1981b). Stages 1 and 2 are believed to be nearly complete within a few million years after emplacement of basalt on the seafloor (Staudigel et al., 1981a, 1981b). Recent work has shown, however, that celadonite and zeolite formation may last as long as $10-20 \mathrm{Ma}$ and overlap the formation of carbonate minerals (Staudigel and Hart, 1985; Staudigel et al., 1986a, 1986b). The temperatures of hydrothermal solutions during stages 1 and 2 range from $15^{\circ}$ to $80^{\circ} \mathrm{C}$ (Lawrence, 1980; Staudigel et al., 1981b).

Stage 3 generally postdates stages 1 and 2 , as evident from crosscutting relationships between vein minerals, and based on $\mathrm{Rb} / \mathrm{Sr}$ and ${ }^{87} \mathrm{Sr} /{ }^{86} \mathrm{Sr}$ dating. For most of the Deep Sea Drilling Project (DSDP) sites studied, carbonate precipitation appears to have occurred in fluids with oxygen and strontium isotope ratios similar to contemporaneous seawater; that is, in relatively open systems in which seawater is still circulating rapidly enough to prevent mineralogical reactions from significantly altering the pore-fluid chemistry (Anderson and Lawrence, 1976; Anderson, 1980; McKenzie, 1980; Staudigel et al., 1981a, 1981b). Thus, the strontium isotope ratios of secondary carbonates are frequently used to estimate the timing and duration of carbonate precipitation (e.g., Hart and Staudigel, 1978, 1979, 1983; Richardson et al., 1980; Staudigel et al., 1986b). Stage 3 alteration lasts 10-15 Ma, possibly longer (Staudigel et al., 1981a, 1986b).

At some sites, however, such as DSDP Site 504B, rapid burial of the basalts isolates them from overlying seawater, and substantial basaltic $\mathrm{Sr}$ is incorporated into the carbonates (Staudigel and Hart, 1985). Such closure of the diagenetic system precludes use of the strontium isotope ratio of the carbonates to date their formation. The oxygen isotopic composition of carbonates formed in closed systems may be similarly affected (Anderson, 1980; Staudigel and Hart, 1985). Closed-system diagenesis is also thought to decrease the pore-fluid $\mathrm{Sr} / \mathrm{Ca}$ ratio, resulting in carbonates with very low strontium contents (Staudigel et al., 1981a; Hart and Staudigel, 1983).

During stage 3 of alteration, the only important elemental exchange between seawater and basalt is the release of calcium and the uptake of magnesium (Staudigel et al., 1981b). Evidence for this exchange may be seen in the chemical gradients of dissolved calcium and magnesium in sediments overlying very old oceanic crust (e.g., Lawrence et al., 1975; Gieskes, 1981). Based on oxygen isotope ratios, carbonate minerals typically form at temperatures that range from $5^{\circ}$ to $40^{\circ} \mathrm{C}$ (Javoy and Fouillac, 1979; Lawrence, 1980; Staudigel et al., 1981b). During stage 4 , the bulk chemistry of oceanic crust does not change, nor are significant amounts of secondary minerals formed (Staudigel et al., 1981a).

Lawrence and Taviani (1988) recently presented the results of a study on secondary carbonates recovered on DSDP Leg 38 from the Norwegian Sea that had unusually light carbon and oxygen isotopic values. Pore waters from the site also had unusually light hydrogen isotopes. The light carbon and hydrogen isotopes were attributed to oxidation of mantle-derived methane (Lawrence and Taviani, 1988). The light oxygen isotopes are thought to be the result of extensive basalt alteration (Lawrence and Taviani, 1988).

\section{LITHOSTRATIGRAPHY}

Detailed lithostratigraphic descriptions of Sites 707 and 715 may be found in Backman, Duncan, et al., 1988. The pertinent results of this work are presented below.

\section{Site 707}

Basaltic basement rocks were drilled from 375.6 to $443.2 \mathrm{~m}$ below seafloor (mbsf). Immediately overlying the basement rocks is a partially dolomitized shallow-water limestone unit. This unit was originally a skeletal packstone with abundant bivalve and gastropod shells. The limestone was subsequently dolomitized and most of the skeletal elements dissolved, so that it now has considerable shell-moldic porosity. Five basalt units, each representing an individual flow, were encountered, along with thin intercalated limestones above and below the fourth basalt flow. All of the flows are clinopyroxene-plagioclase basalts. Units 1, 3 , and 5 are $5-10 \mathrm{~m}$ thick. Unit 2 is $0.62 \mathrm{~m}$ thick, and Unit 4 is $36.7 \mathrm{~m}$ thick. The upper portions of the flows are moderately vesicular and moderately altered. The primary alteration phases are abundant brown clays (probably smectites) that replace interstitial glass, and carbonates deposited in vesicles and veins. Where both are present, the carbonates are a later precipitate than the clays (Fig. 2).

\section{Site 715}

Basalts were drilled from 211.2 to $287.8 \mathrm{mbsf}$. As at Site 707, the limestone unit overlying the basalt was a shallow-water skeletal packstone with well-developed moldic porosity, although not dolomitized. Identifiable skeletal elements included calcareous algae, shallow-water benthic foraminifers, corals, and bryozoans.

The basement rocks were subdivided into 21 separate units. Individual flows were generally thin, on the order of 1-2 m. The upper four basalt units are aphanitic to fine-grained phaneritic plagioclase basalts. The lower units are olivine plagioclase basalts. The most conspicuous feature of the basalts at Site 715 is the highly weathered and oxidized upper surface of a number of the basalt flows. Limonite and hematite are common alteration products. Also, basalt-limestone breccias with red, weathered basalt fragments, which may represent paleoregoliths, overlie some of the basalt flows (Fig. 3). Other alteration products include green and brown clays, which replace groundmass or olivine crystals. Secondary carbonates are also common, particularly in vesicles. In a number of instances, vesicles lined with yellow clays have carbonates precipitated on top of the clay minerals.

\section{METHODS}

For mineralogical and elemental analyses, approximately one half of each sample was broken into pieces. The fragments containing only the secondary carbonates were powdered in an agate mortar and pestle. The samples were analyzed for mineralogy by standard X-ray diffraction (XRD) techniques on a Phillips X-ray Diffraction Unit. Approximately $250 \mathrm{mg}$ of powdered sample was leached in $1 \mathrm{~N} \mathrm{HCl}$ for $30 \mathrm{~min}$. The solution was then filtered through $0.45-\mu \mathrm{m}$ cellulose nitrate filters and analyzed for calcium, magnesium, strontium, iron, and manganese by standard flame atomic absorption spectrometry techniques on a Perkin-Elmer Model 5000 atomic absorption spectrophotometer.

Samples for carbon and oxygen stable isotope analyses were obtained by direct microdrilling of the secondary carbonates within the basalts. Stable isotope ratios were determined on a Finnegan Mat 251 ratio mass spectrometer. Samples were reacted in $100 \%$ phosphoric acid at $50^{\circ} \mathrm{C}$ for $4 \mathrm{hr}$ or until reaction had ceased (McCrea, 1950). All results are reported relative to the PDB standard. The phosphoric acid fractionation factor for calcite ( $\alpha=1.0094$ at $50^{\circ} \mathrm{C}$; P. K. Swart, unpubl. data) was applied to both calcites and dolomites. The phosphoric acid fractionation factor for siderites reported by Carothers et al. (1988) was used to correct siderite values. 


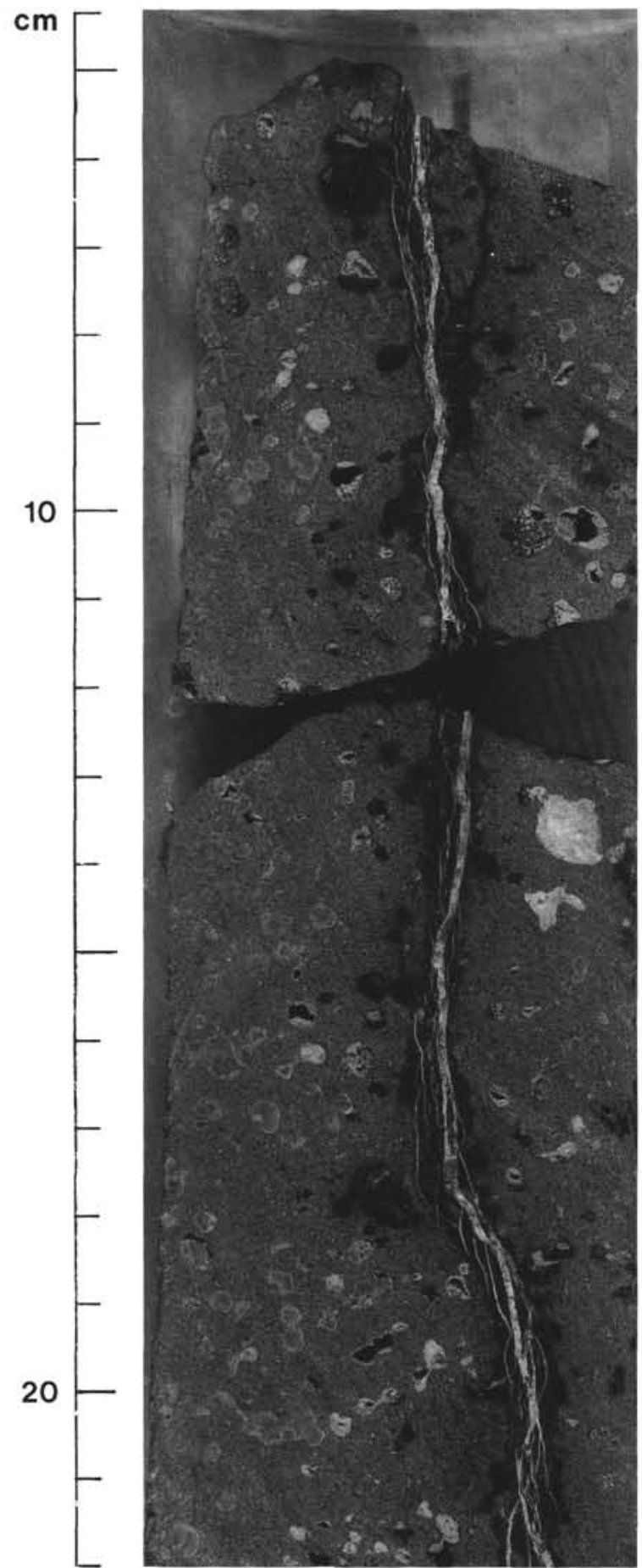

Figure 2. Basalt from Hole $707 \mathrm{C}$ with vein and numerous vesicles filled with clay minerals (dark) and aragonite (white). Aragonite crosscuts clay minerals in vein. Sample 115-707C-28R-2, 4-22 cm.

\section{RESULTS}

The results of mineralogic, isotopic, and trace element analyses are presented in Table 1 and Figures 4-6.

\section{Mineralogy}

\section{Site 707}

The secondary carbonates and the limestones intercalated with the basalts at Site 707 exhibit a variety of rock types. The

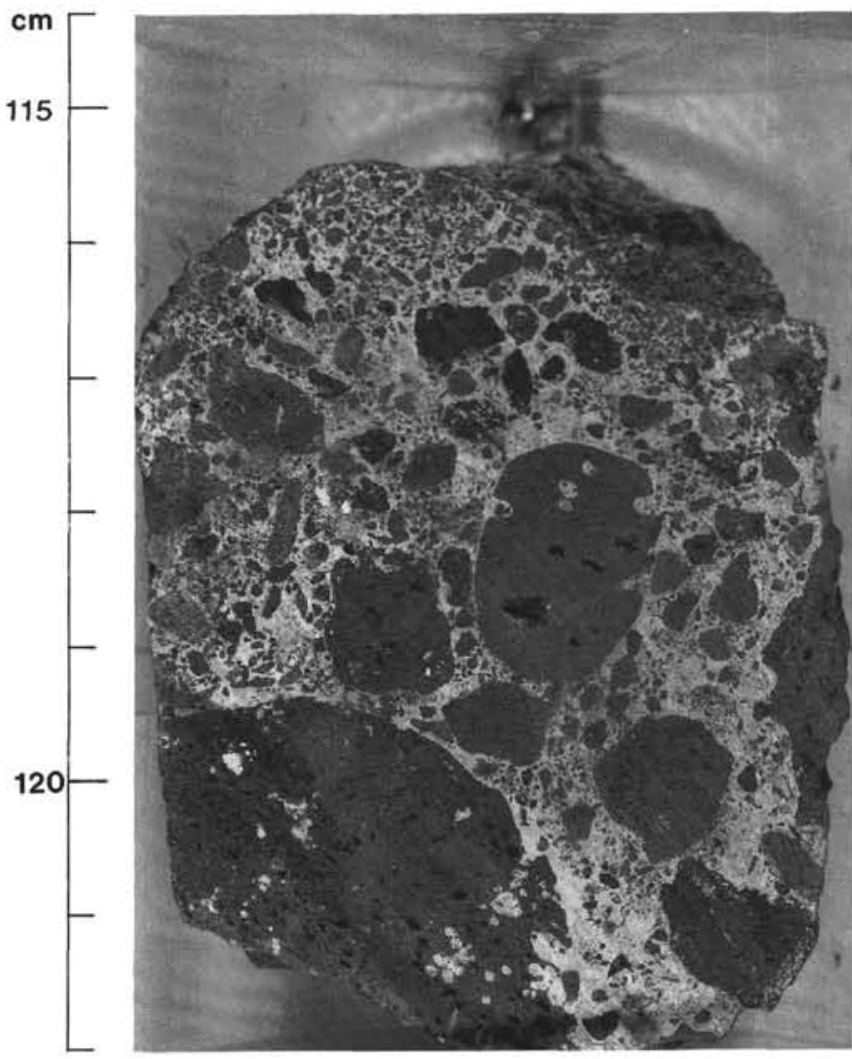

Figure 3. Calcite-cemented basalt conglomerate from the top of basalt Unit 1, Hole 715. Sample 115-715A-23R-2, 114-122 cm.

most common mineral in the sedimentary carbonate layers studied is calcite. The sedimentary rocks are also composed of (see Table 1) dolomite (Samples 115-707C-21R-1, 30-31 cm, and 115-707C-28R-1, 1-3 cm), mixed dolomite and calcite (Sample 115-707C-21R-1, 20-22 cm), and mixed calcite and siderite (Sample $115-707 \mathrm{C}-24 \mathrm{R}-1,80-86 \mathrm{~cm}$ ).

The secondary carbonates are primarily aragonite, and a number of the samples are calcite (Table 1). Several of the samples are very unusual carbonates that are mixtures of calcite, manganese-rich siderite, and dolomite, with a large degree of solid solution mixing of different cations within different minerals. Sample 115-707C-28R-2, $58-59 \mathrm{~cm}$, for example, is composed of only one ankerite-like, carbonate phase, based on XRD, yet its chemical composition is approximately $60 \mathrm{~mol}_{0} \mathrm{FeCO}_{3}, 9$ $\mathrm{mol}_{0} \mathrm{CaCO}_{3}$, and $30 \mathrm{~mol} \% \mathrm{MgCO}_{3}$. Other samples are two phases; for example, Sample 115-707C-25R-1, 15-16 cm, consists of a very high-magnesium calcite and manganese-rich siderite.

\section{Site 715}

In contrast to Site 707 , all samples of secondary carbonates and sedimentary carbonates at Site 715 are low-magnesium calcite.

\section{Stable Isotopes}

\section{Site 707}

With two exceptions, the oxygen isotopic composition of all of the secondary and sedimentary carbonates at Site 707 fall within a fairly narrow range of values, from $-0.1 \%$ to $-2.28 \%$. The two samples that have different values are 115 707C-28R-1, 1-3 cm, and 115-707C-28R-1, 12-13 cm, which have oxygen isotope values of -5.64 and -6.27 , respectively. 
Table 1. Mineralogy and geochemistry of samples from Sites 707 and 715.

\begin{tabular}{|c|c|c|c|c|c|c|c|c|c|}
\hline $\begin{array}{l}\text { Core, section, } \\
\text { interval }(\mathrm{cm})\end{array}$ & Type & $\begin{array}{l}\text { Rock } \\
\text { type }\end{array}$ & $\begin{array}{l}\text { Depth } \\
\text { (mbsf) }\end{array}$ & $\delta^{18} \mathrm{O}$ & $\delta^{13} \mathrm{C}$ & $\underset{(\mathrm{mol} \%)}{\mathrm{Mg}}$ & $\underset{(\mathrm{ppm})}{\mathrm{Sr}}$ & $\begin{array}{c}\mathrm{Mn} \\
(\mathrm{ppm})\end{array}$ & $\begin{array}{c}\mathrm{Fe} \\
(\mathrm{ppm})\end{array}$ \\
\hline \multicolumn{10}{|l|}{$115-707 \mathrm{C}$} \\
\hline $21 \mathrm{R}-1,20-22$ & $\mathrm{~s}$ & $C+D$ & 365.3 & -1.16 & 1.52 & & & & \\
\hline $21 \mathrm{R}-1,30-31$ & $\mathrm{~s}$ & D & 365.3 & 1.17 & -0.29 & & & & \\
\hline $22 \mathrm{R}-1,53-55$ & $\mathrm{~s}$ & C & 376.0 & -0.10 & -2.38 & & & & \\
\hline $22 \mathrm{R}-1,83-85$ & Vs & C & 376.4 & -0.43 & -2.79 & 3.30 & 235 & 1,790 & 14,700 \\
\hline $23 R-2,72-74$ & Vs & A & 387.0 & -0.93 & -9.17 & 1.22 & 7,370 & 209 & 11,000 \\
\hline $24 \mathrm{R}-1,5-8$ & $\mathrm{~s}$ & C & 394.8 & -1.50 & 1.19 & & & & \\
\hline $24 \mathrm{R}-1,30-32$ & $\mathrm{~S}$ & C & 395.0 & -2.28 & 0.90 & & & & \\
\hline $24 \mathrm{R}-1,44-46$ & $\mathrm{~s}$ & C & 395.2 & -2.09 & 1.07 & 2.99 & 262 & 5,540 & 3,670 \\
\hline $24 \mathrm{R}-1,69-71$ & $\mathrm{~S}$ & C & 395.5 & -1.64 & 1.11 & & & & \\
\hline $24 \mathrm{R}-1,80-86$ & $\mathrm{~S}$ & C & 395.6 & -1.05 & 0.15 & 10.30 & 516 & 4,170 & 89,500 \\
\hline $24 \mathrm{R}-1,86-89$ & $\mathrm{~S}$ & $C+S$ & 395.7 & -1.25 & -0.47 & & & & \\
\hline $24 \mathrm{R}-3,15-16$ & Vs & C & 398.0 & -1.20 & -8.68 & & & & \\
\hline $24 \mathrm{R}-3,35-38$ & Vs & C & 398.2 & -1.45 & -5.46 & 2.41 & 145 & 5,280 & 13,400 \\
\hline $25 \mathrm{R}-1,15-16$ & $\mathrm{Vn}$ & $S+C$ & 404.7 & -2.03 & -2.64 & 22.70 & 206 & 26,200 & 179,000 \\
\hline $25 \mathrm{R}-1,80-82$ & Vn & A & 405.3 & -0.68 & -3.84 & 0.64 & 8,050 & 344 & 3,080 \\
\hline $25 \mathrm{R}-3,34-38$ & $\mathrm{Vn}$ & C & 407.6 & -0.67 & -3.79 & 2.51 & 862 & 6,870 & 10,000 \\
\hline $26 \mathrm{R}-2,56-57$ & Vn & A & 416.2 & -1.43 & -14.46 & 0.14 & 6,900 & 37 & 665 \\
\hline $27 \mathrm{R}-1,70-72$ & $V_{n}$ & A & 424.5 & -1.27 & -16.43 & & & & \\
\hline $27 \mathrm{R}-4,105-106$ & Vn & A & 429.0 & -1.54 & -12.17 & 0.34 & 7,710 & 365 & 2,890 \\
\hline $27 \mathrm{R}-6,130-140$ & Vn & $\mathrm{s}$ & 432.2 & -0.62 & -5.68 & & & & \\
\hline $28 \mathrm{R}-1,1-3$ & $\mathrm{~S}$ & D & 432.4 & -5.64 & -1.89 & 2.60 & 356 & 4,070 & 4,060 \\
\hline $28 \mathrm{R}-1,12-13$ & $\mathrm{~S}$ & C & 432.5 & -6.27 & -2.62 & & & & \\
\hline $28 \mathrm{R}-2,6-7$ & Vs & A & 435.0 & -1.81 & -5.88 & & & & \\
\hline $28 \mathrm{R}-2,27-28$ & Vs & A & 435.3 & -1.63 & -5.04 & 0.73 & 6,030 & 967 & 5,740 \\
\hline $28 \mathrm{R}-2,42-43$ & Vs & C & 435.6 & -0.54 & -3.35 & & & & \\
\hline $28 \mathrm{R}-2,42-43$ & Vs & $\mathrm{s}$ & 435.6 & 0.10 & -6.29 & & & & \\
\hline $28 \mathrm{R}-2,58-59$ & Vs & $\mathrm{s}$ & 435.6 & -0.30 & -7.76 & 56.26 & 642 & 10,900 & 289,000 \\
\hline $28 R-2,75-76$ & Vs & $\mathrm{S}$ & 435.8 & -0.02 & -6.73 & & & & \\
\hline $28 \mathrm{R}-2,129-130$ & Vs & A & 436.4 & -1.49 & -4.46 & 0.17 & 5,190 & 77 & 1,310 \\
\hline $28 \mathrm{R}-3,3-4$ & Vs & A & 436.6 & -1.45 & -5.46 & 0.14 & 6,290 & 36 & 1,270 \\
\hline $28 \mathrm{R}-3,29-30$ & Vs & A & 436.9 & -1.78 & -9.85 & 0.25 & 7,530 & 51 & 1,970 \\
\hline \multicolumn{10}{|l|}{$115-715 \mathrm{~A}-$} \\
\hline 20R-CC & $\mathrm{s}$ & C & & -1.10 & 1.68 & & & & \\
\hline $21 \mathrm{R}-1,40-42$ & $\mathrm{~S}$ & C & & -1.99 & 1.76 & & & & \\
\hline $21 \mathrm{R}-1,60-62$ & $\mathrm{~s}$ & C & & -0.74 & 1.77 & & & & \\
\hline $23 \mathrm{R}-1,25-27$ & $\mathrm{~S}$ & C & 211.2 & -1.88 & 0.61 & 2.10 & 265 & 775 & 232 \\
\hline 23R-1, 100-104 & $\mathrm{S}$ & C & 211.9 & -1.22 & 0.74 & & & & \\
\hline $23 R-2,144-146$ & Vs & C & 213.8 & 1.17 & 1.94 & 2.20 & 125 & 112 & 177 \\
\hline $24 \mathrm{R}-1,40-42$ & Vs & C & 220.9 & 1.53 & 1.92 & 2.90 & 200 & 1,130 & 220 \\
\hline $25 \mathrm{R}-1,47-50$ & $\mathrm{~s}$ & C & 230.5 & -2.24 & 0.82 & 2.50 & 277 & 269 & 126 \\
\hline $25 \mathrm{R}-1,77-79$ & Vs & $\mathrm{C}$ & 230.8 & 1.43 & 0.55 & 2.70 & 161 & 3,430 & 715 \\
\hline $25 R-2,9-10$ & Vs & C & 231.6 & 2.20 & -2.75 & 2.80 & 173 & 496 & 739 \\
\hline $25 \mathrm{R}-2,61-63$ & $V_{n}$ & $\mathrm{C}$ & 232.1 & 1.52 & 0.97 & 2.60 & 247 & 841 & 670 \\
\hline $25 \mathrm{R}-3,72-74$ & Vs & C & 233.1 & 0.11 & 0.87 & 2.90 & 187 & 1,340 & 889 \\
\hline $25 \mathrm{R}-3,124-125$ & $V_{n}$ & C & 234.3 & 1.86 & -0.74 & & & & \\
\hline $25 \mathrm{R}-3,128-131$ & Vs & C & 233.7 & 1.89 & 1.08 & & & & \\
\hline 2SR-5, 82-84 & Vs & C & 236.8 & 2.86 & 1.42 & 2.50 & 166 & 4,720 & 1,310 \\
\hline $26 \mathrm{R}-1,97$ & $\mathrm{Vn}$ & C & 240.5 & 0.80 & -2.37 & 3.20 & 221 & 11,400 & 1,060 \\
\hline $26 \mathrm{R}-2,103-105$ & Vs & C & 242.0 & -0.27 & 1.72 & & & & \\
\hline $26 \mathrm{R}-2,139-140$ & Vs & C & 242.4 & 0.23 & 1.28 & 2.50 & 173 & 535 & 226 \\
\hline $30 \mathrm{R}-3,118-120$ & $\mathrm{Vn}$ & C & 271.9 & 1.19 & -1.84 & 2.80 & 189 & 8,350 & 1,030 \\
\hline $30 \mathrm{R}-5,27-28$ & Vs & C & 278.2 & -0.19 & 1.38 & 2.70 & 176 & 8,740 & 1,080 \\
\hline $31 \mathrm{R}-2,118-119$ & Vs & C & 280.7 & 0.11 & 0.42 & 2.40 & 212 & 744 & 169 \\
\hline $31 R-3,21-22$ & Vs & $\mathrm{C}$ & 281.5 & 0.60 & 1.63 & 2.60 & 154 & 388 & 196 \\
\hline
\end{tabular}

Notes: $\mathrm{S}=$ sediment, $\mathrm{Vs}=$ vesicle, $\mathrm{V} \mathrm{n}=$ vein, $\mathrm{C}=$ calcite, $\mathrm{D}=$ dolomite, $\mathrm{A}=$ aragonite, and $\mathrm{S}=$ siderite.

Both of these samples are from a sedimentary carbonate unit found between basalt Units 4 and 5 . The carbon isotope values of the sedimentary carbonates vary from $-2.62 \%$ to $1.52 \%$, generally within the range of normal marine carbonates. The secondary carbonates, on the other hand, display a wide range of carbon isotope ratios, and nearly all of them are significantly depleted in the heavy isotope. Carbon isotope values for the secondary mineral phases range from $-2.64 \%$ to $-16.43 \%$. The lightest values are primarily aragonites.

\section{Site 715}

The oxygen isotope values of the secondary and sedimentary carbonates from Site 715 fall within narrow but distinctly differ- ent ranges. The sediments range from $-0.74 \% 0$ to $-2.24 \%$, whereas the basalt precipitates range from $-0.27 \%$ to $2.86 \%$. The carbon isotope values of the limestones range from $0.74 \%$ to $1.77 \%$. For the secondary carbonates, carbon isotope values are from $-3.55 \%$ to $1.94 \%$, the majority of the values being positive.

\section{Trace Elements}

\section{Site 707}

The trace element contents of the samples from Site 707 are highly dependent on mineralogy (Fig. 6). Aragonite samples have high strontium contents, generally ranging from 5000 to 


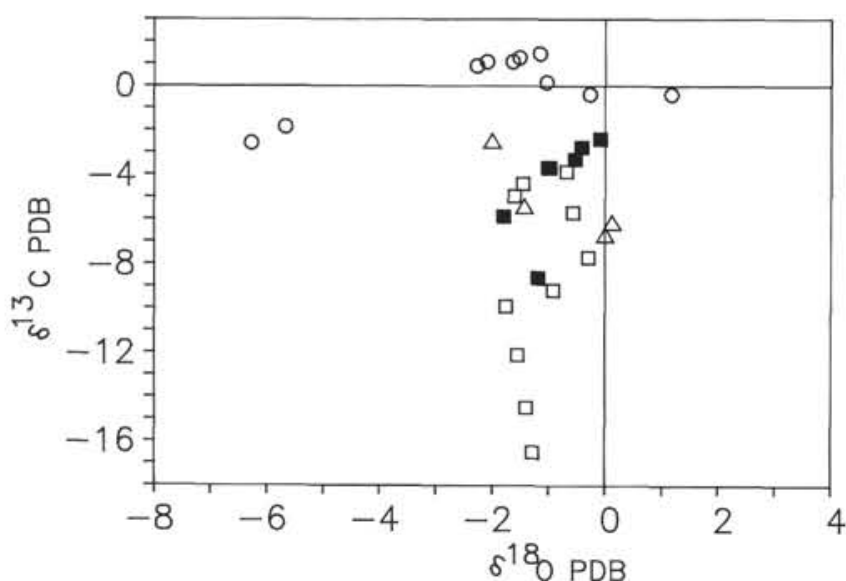

Figure 4. Plot of $\delta^{18} \mathrm{O}$ vs. $\delta^{13} \mathrm{C}$ for samples from Site 707. Open circles $=$ sedimentary carbonates. Other symbols are secondary carbonates. Closed squares $=$ calcite, open squares $=$ aragonite, and triangles $=$ siderite.

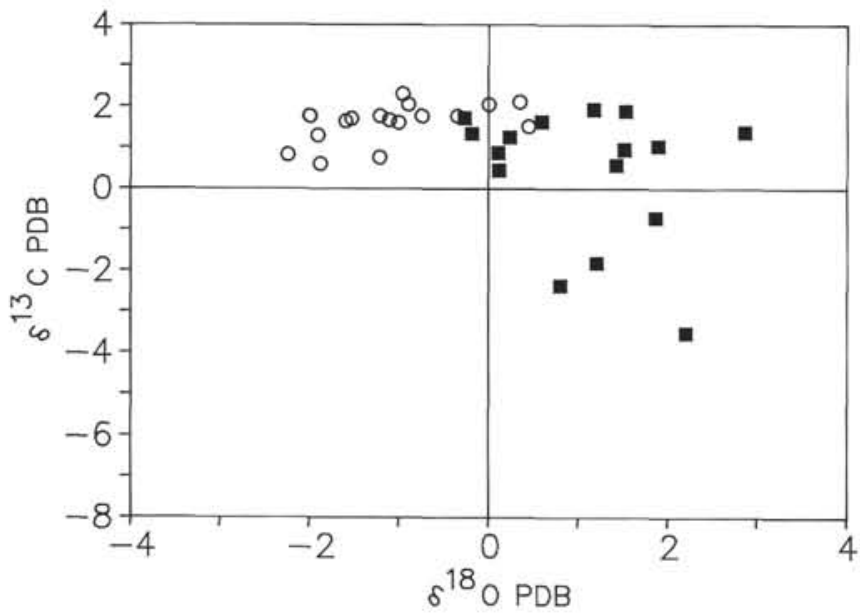

Figure 5. Plot of $\delta^{18} \mathrm{O}$ vs. $\delta^{13} \mathrm{C}$ for samples from Site 715. Symbols as in Figure 4.

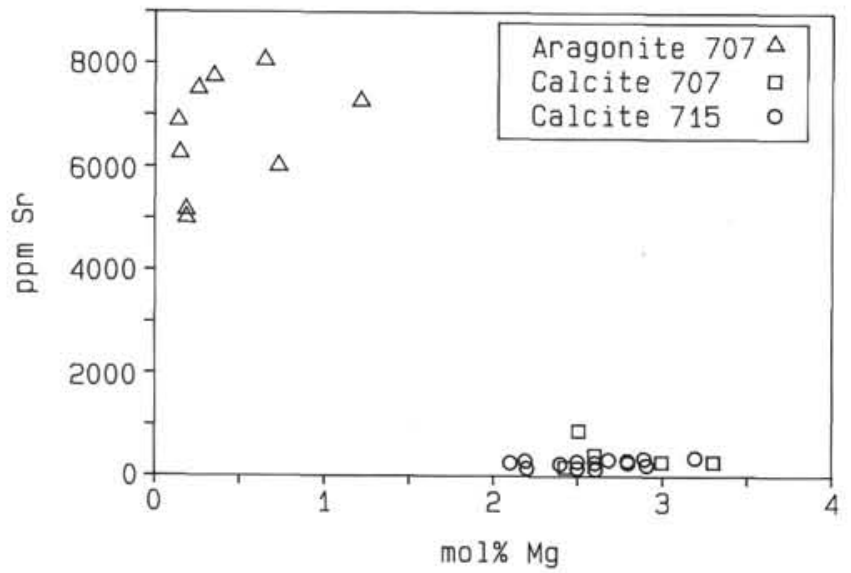

Figure 6. Strontium vs. magnesium for aragonites and calcites from Site 707, and calcites from Site 715 .
$8000 \mathrm{ppm}$. Calcite samples have much lower strontium contents, from 145 to $862 \mathrm{ppm}$. For samples with more complex rock types, the strontium values are generally greater, around 500 to $800 \mathrm{ppm}$. For all samples, strontium is presented as ppm relative to all the carbonate phases present. Iron and manganese contents of the aragonites are low relative to calcites, which have up to several mol\% manganese and iron. The siderite samples all have very high manganese contents.

\section{Site 715}

The calcites from Site 715 have strontium contents similar to those from Site 707 (Fig. 6), generally between 100 and 200 ppm. The iron and manganese contents of the Site 715 samples are quite variable, but they are generally much lower than at Site 707 (Table 1).

\section{DISCUSSION}

Secondary carbonates, and to some degree the sedimentary carbonates, from Site 707 exhibit very different mineralogical and chemical compositions than those of Site 715. The mineralogical and chemical differences between the two sites primarily reflect differences in the degree of openness of the respective diagenetic environments. Other important factors are the environment of extrusion and extent of initial weathering of the basalts, and the thickness of individual basalt layers. The secondary carbonates from Site 715 are typical of carbonates recovered from basalts at a number of DSDP locations (Fig. 7).

Carbonates from Site 707, on the other hand, display mineral and chemical compositions not commonly encountered as alteration products in ocean crust. Apparently, the products of mineralogical reactions occurring within the basalts at Site 707 have been incorporated into the carbonates rather than being returned to the ocean, as is usually the case. Thus, the unusual chemical characteristics of the secondary minerals at Site 707 can be interpreted in terms of the types of chemical exchange that occur between basalt and seawater at low temperatures.

\section{Site 715}

At Site 715 , as at most other DSDP sites where secondary carbonates have been studied (Anderson and Lawrence, 1976; Anderson, 1980; Lawrence, 1980; McKenzie, 1980), the primary

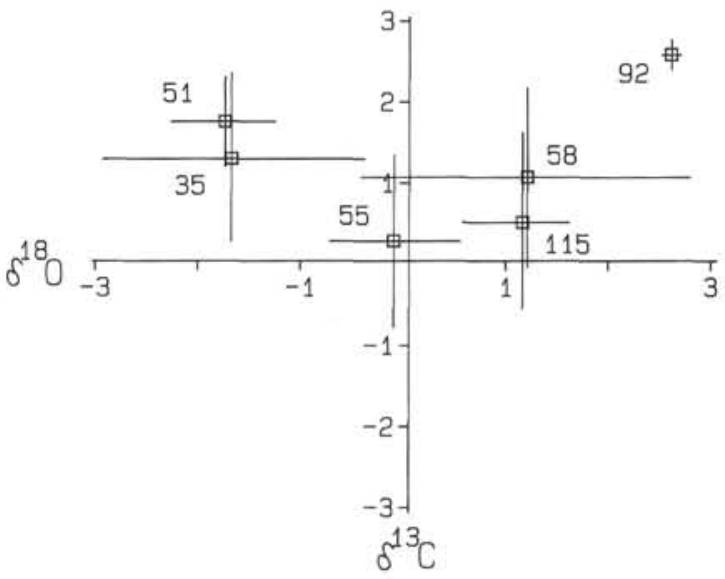

Figure 7. Average values of $\delta^{18} \mathrm{O}$ and $\delta^{13} \mathrm{C}$ for secondary calcites in basalts from DSDP Legs 35 (Anderson and Lawrence, 1976), 51 (Lawrence, 1980), 55 (McKenzie, 1980), 58 (Anderson, 1980), and 92 (Staudigel et al., 1986b), and ODP Leg 115, Site 715 (this chapter). The horizontal and vertical bars represent one standard deviation of the measured values. 
mineral is calcite, which precipitated from fluids of near-seawater composition. The oxygen isotope values (Fig. 7) and strontium contents (Richardson et al., 1980; Staudigel et al., 1981b; Hart and Staudigel, 1983) of the secondary carbonates are similar to those of calcites from DSDP sites where the carbonates were interpreted to have precipitated within basalts through which seawater was still actively circulating. There is, however, some evidence for a basalt-derived component in the pore fluids at Site 715 . The high manganese (up to $3.2 \mathrm{~mol} \%$ ) and iron (up to $1300 \mathrm{ppm}$ ) contents of the secondary carbonates indicate precipitation from reducing fluids with iron and manganese contents considerably higher than seawater values.

The oxygen isotopes of secondary carbonates may be used to estimate their formation temperatures (e.g., Lawrence, 1980). Low-temperature basalt-seawater interaction is generally assumed to have had little effect on the oxygen isotope content of the fluids moving through the basalts and thus on the secondary minerals (Anderson and Lawrence, 1976; McKenzie, 1980; Staudigel et al., 1981a). Although this is not always the case (e.g., Site 504; Staudigel and Hart, 1985), it is probably a reasonable assumption for Site 715 because the diagenetic system appears to have been relaatively open. Estimated formation temperatures for secondary carbonates are presented in Table 2 . The temperatures are derived using an assumed $\delta^{18} \mathrm{O}$ value for the fluids of $-1 \%$ relative to Standard Mean Ocean Water (SMOW), an approximate value for early Tertiary seawater. On the basis of these calculations, the estimated formation temperatures for the secondary carbonates at Site 715 are quite low, on the order of $2^{\circ}-10^{\circ} \mathrm{C}$.

The sequence of rocks at this site and their apparent diagenetic environments record a series of emergence and submergence events as follows: (1) subaerial extrusion of the basalts, based on the highly oxidized and weathered character of the upper surfaces of individual flows, and on the presence of secondary limonite, hematite, and limestone-cemented basalt-pebble conglomerates; (2) submergence and subsequent deposition and accumulation of shallow-marine limestones, in between subaerially weathered basalts as well as on top of the youngest basalt flow; (3) a second period of subaerial (freshwater) diagenesis, indicated by the shell-moldic porosity and light oxygen isotope values of the limestones located above the youngest basalt flow and in between flows; and (4) permanent submergence and eventual deposition of secondary carbonates in the marine environment.

\section{Site 707}

The secondary carbonates from Site 707 record a very different diagenetic setting than those from Site 715 . The rock types

Table 2. Estimated formation temperatures.

\begin{tabular}{cccc}
\hline Site & $\begin{array}{c}\text { Core, section, } \\
\text { interval (cm) }\end{array}$ & $\delta^{18} \mathrm{O}$ & $\mathrm{T}^{\circ} \mathrm{C}^{\mathrm{a}}$ \\
\hline 715 & $25 \mathrm{R}-5,82-84$ & 2.86 & \multicolumn{1}{c}{2} \\
& $26 \mathrm{R}-2,102-105$ & -0.27 & 13.3 \\
707 & $\mathrm{~b}_{25 \mathrm{R}-1,80-82}$ & -0.68 & 15 \\
& b28R-3, 29-30 & -1.78 & 19.6 \\
& $\mathrm{c}_{22 \mathrm{R}-1,53-55}$ & -0.1 & 12.5 \\
& $\mathrm{c}_{24 \mathrm{R}-3,35-38}$ & -1.45 & 18.3 \\
& $\mathrm{~d}_{28 \mathrm{R}-1,12-13}$ & -6.27 & 42.7 \\
\hline
\end{tabular}

a Based on the calcite-water temperature equation of Epstein et al. (1953) and assuming $\delta^{18} \mathrm{O}_{\mathrm{H}_{2} \mathrm{O}}=-1 \%_{0}$ SMOW.

b Aragonite.

c Calcite.

d Sedimentary calcite below basalt Unit 4 . of the samples, their carbon isotope ratios, possibly oxygen isotope ratios, and their trace element compositions all reflect formation from a fairly closed pore-water/basalt system. Exchange, or circulation of overlying seawater through the basalts during the latter stages of diagenesis, was sluggish enough to allow basalt-seawater interaction to influence the pore-fluid composition greatly and to allow the precipitating carbonates to record those changes.

The mineralogies of the secondary carbonates at Site 707 include phases not previously reported to occur as late-stage precipitates in basalts. The presence of siderite and very iron- and manganese-rich calcites clearly indicates that the carbonates formed from reduced pore fluids with iron and manganese contents greatly enriched relative to seawater. The only possible source of iron and manganese is the basalts. Incorporation of these elements into carbonate minerals could only have occurred in a basalt/pore-fluid system in which the rates of chemical reaction were rapid relative to flow rates of circulating seawater.

The presence of aragonite is also somewhat unusual, although aragonite has been previously reported as a secondary carbonate at several DSDP sites (e.g., McKenzie, 1980; Staudigel and Hart, 1985). Aragonite is more soluble than calcite in seawater, and, thus, it is not the stable $\mathrm{CaCO}_{3}$ mineral. Calcite precipitation in seawater, however, is known to be inhibited kinetically and slow relative to aragonite precipitation (Berner, 1975). The presence of aragonite, therefore, indicates that alteration reactions occurring within the basalts were adding either calcium or bicarbonate, or both, to the pore fluids faster than they could be incorporated into calcite, allowing aragonite solubility to be exceeded and aragonite to precipitate.

Despite the evidence for a closed diagenetic system, the strontium contents of the aragonites and calcites indicate pore-fluid $\mathrm{Sr} / \mathrm{Ca}$ ratios near that of seawater. The aragonites contain 5000 to $8000 \mathrm{ppm} \mathrm{Sr}$, values very similar to those found in inorganic precipitates formed from normal seawater such as ooids or aragonite cements (Milliman, 1974). In contrast, the only other measured value for a secondary aragonite is $1660 \mathrm{ppm}$, from Site 504B (Staudigel and Hart, 1985). The strontium contents of the calcites are also similar to the strontium contents of secondary calcites from DSDP sites where the calcites precipitated from unaltered seawater (Hart and Staudigel, 1979). The high strontium contents of the secondary carbonates from Site 707 indicate that caution should be exercised in using high strontium contents as an indicator of open-system diagenesis, as has been suggested (Staudigel et al., 1981b; Hart and Staudigel, 1983). At Site 707 , secondary carbonates have high strontium contents even though there is evidence for a significant basaltic component in the pore fluids.

Perhaps the most unusual aspect of the secondary carbonates from Site 707 is their carbon isotope ratios. Without exception, the sample carbon isotope ratios are depleted in ${ }^{13} \mathrm{C}$, with values as light as $-16.4 \%$ (Table 1 ). The only previously reported secondary carbonates from within basalts with such light carbon isotope values are from DSDP Leg 38 (Lawrence and Taviani, 1988), where values as light as $-52 \%$ PDB were found. The light values found in DSDP Leg 38 samples effectively ruled out any carbon source except methane (Lawrence and Taviani, 1988). And based on mass balance calculations for carbon and hydrogen isotopes, the source of methane to the pore fluids was interpreted to be methane introduced into the basalts, after eruption, from the mantle (Lawrence and Taviani, 1988). Most of the carbonates studied by Lawrence and Taviani (1988) had carbon isotope values between $-10 \%$ and $-30 \%$ PDB, values that are considerably lighter than the generally accepted value for mantle carbon (i.e., - 7\% PDB; Dienes, 1980).

The isotopic composition of methane outgassing from oceanic basalts has also been directly measured. East Pacific Rise 
hydrothermal fluids contained methane with carbon isotope values that ranged from $-15 \%$ to $-17.6 \%$ (Welhan et al., 1981) and outgassing methane from Iceland was $-23 \%$ (Poreda et al., 1984). Ocean-ridge basalts themselves contain isotopically "heavy" ( $-5 \%_{0}$ to $-9 \%_{0}$ PDB) and "light" $\left(-10 \%_{0}\right.$ to $-30 \%_{0}$ PDB) carbon components (e.g., Pineau et al., 1976; Exley et al., 1986). At this time, there is no universally accepted source of the "light" carbon component in basalts. Possibilities include a true mantle component, contamination by organic carbon, or a fractionation of the total initial carbon pool into light and heavy fractions (see Pineau and Javoy, 1983; Exley et al., 1986, 1987; Craig, 1987).

Although the ultimate origin of light carbon in basalts is a complex and unresolved problem, we believe that there are three important reasons why the light carbon in the Site 707 secondary carbonates is derived from fluids circulating within basalts and not from seawater, or modified seawater, circulating through the overlying sediments. First, the evidence for a significant basaltic component in the pore fluids at Site 707 implies that the exchange of fluids between the upper basement and overlying sediments was minimal. Second, the only other realistic source of isotopically light carbon is organic matter. Yet, the organic carbon content of the sediments overlying the basalts is extremely low, below the detection limits of the initial shipboard measurements (Backman, Duncan, et al., 1988). Third, the range of carbon isotope values seen in the carbonates at Site 707 could have been produced by the oxidation of methane with the isotopic compositions observed by Welhan et al. (1981) and Poreda et al. (1984) for methane outgassing from oceanic basalts. The ultimate source of the methane in the basalts is not clear, however, and may have been (1) unusually light mantle carbon, (2) a fractionated portion of the total carbon in the basalt, or (3) sedimentary organic carbon that was somehow incorporated into the basalts during earlier circulation of hydrothermal fluids through the rocks.

For the methane carbon to be incorporated into the carbonates, it must be oxidized. Several possible oxidants exist; they include ferric iron in the basalts and sulfate from the pore fluids and from sulfate minerals deposited in the basalt during higher temperature interaction with seawater (Lawrence and Taviani, 1988). Both sources may have been used. The former would account for the high concentrations of reduced iron present in the system. The latter, with the following stoichiometry,

$$
\mathrm{CH}_{4}+\mathrm{SO}_{4}^{2-}=\mathrm{HCO}_{3}^{-}+\mathrm{HS}^{-}+\mathrm{H}_{2} \mathrm{O} \text {, }
$$

would also be a source of bicarbonate.

Rapid methane oxidation by way of sulfate reduction may also explain why aragonite is precipitated, and why the aragonites have the lowest carbon isotope values. As explained earlier, a rapid increase in either the calcium or bicarbonate content of the pore fluids is necessary to account for aragonite rather than calcite precipitation as a secondary phase. It seems unlikely that, at low temperatures, production of calcium from basalt/ pore-fluid interaction would be rapid enough to cause supersaturation of aragonite. At most DSDP sites where the release of calcium leads to $\mathrm{CaCO}_{3}$ precipitation, the mineralogy is calcite (Staudigel et al., 1981a). The above reaction is a possible mechanism for increasing bicarbonate quickly, leading to aragonite precipitation.

The oxygen isotope composition of the Site 707 secondary carbonates may have also been affected by closed-system diagenesis. If we attempt to use them to estimate formation temperatures at Site 715 , initially assuming little basalt/pore-fluid interaction and thus a pore-fluid oxygen isotope value of $-1 \%$ SMOW, then formation temperatures were on the order of $12^{\circ}-$ $20^{\circ} \mathrm{C}$ (Table 2). Significant interaction of the pore fluids with the basalts, however, would result in fluids that were isotopically lighter than coeval seawater (Lawrence, 1973; Lawrence et al., 1975; Muehlenbachs, 1979). Thus, the calculated formation temperatures must be considered maximum temperatures.

The oxygen isotopic compositions of the majority of the sedimentary carbonates cannot be used to estimate their formation temperatures. The abundant moldic porosity and generally recrystallized textures of these rock points are evidence of a stage of freshwater diagenesis, which would have a marked effect on their oxygen isotopes. Two of the sedimentary samples from Site 707 , those from below basalt Unit 4, have quite depleted oxygen isotope ratios. They may have been recrystallized at elevated temperatures, on the order of $40^{\circ}-50^{\circ} \mathrm{C}$ (Table 2). This is consistent with their stratigraphic position below a $37-\mathrm{m}$-thick basalt flow.

Two final questions are worth considering. First, is the Site 707 secondary carbonates' unusual chemistry indicative of reactions taking place at low temperatures, or are the products of higher temperature alteration trapped in the basalt and only later incorporated into carbonate minerals formed at lower temperatures? The latter sequence of events requires that the basalt/pore-fluid system be isolated from overlying pore fluids and seawater at an early stage of diagenesis. This may be possible, but it seems unlikely that warm fluids in the basalts would not be driven upward by thermal convection. Furthermore, the presence of aragonite, formed at low temperatures, indicates that reactions producing calcium and bicarbonate were occurring at low temperatures.

Second, why are the secondary carbonates from Sites 707 and 715 so different? Site 707 carbonates precipitated in a fairly closed system, Site 715 carbonates in a much more open system. At Site 707, high sedimentation rates, on the order of $12 \mathrm{~m} / \mathrm{m} . \mathrm{y}$. (Backman, Duncan, et al., 1988) in the sediments overlying the basalts, may be responsible for preventing extensive late circulation of seawater through the basalts. Though precise estimates of the sedimentation rate for the sediments overlying the basalts at Site 715 are not available, the lower $100 \mathrm{~m}$ of the sedimentary column are all early Eocene shallow-water limestones, indicating a high sedimentation rate similar to Site 707 . Why high sedimentation rates at Site 715 did not also result in evidence of closed-system diagenesis is not clear. The most obvious difference between the two sites is the evidence for subaerial weathering at Site 715. Subaerial weathering and cooling may have been extensive enough to have altered Site 715 basalts enough before burial that little further diagenesis took place.

\section{SUMMARY AND CONCLUSIONS}

Secondary carbonates precipitated within basalts at Site 715 are all composed of calcite. The calcites probably were precipitated from pore fluids of near-seawater composition, at temperatures that ranged from $2^{\circ}$ to $10^{\circ} \mathrm{C}$. The iron and manganese contents of the calcites, however, are considerably higher than would be expected for seawater precipitates, indicating that some basalt/seawater interaction did take place.

In contrast, Site 707 secondary carbonates were precipitated from a much more closed diagenetic system. Thus, their chemistry has been influenced by basalt/seawater interaction. Although Site 707 is not necessarily representative of basalt/seawater interaction everywhere, the chemistry of the secondary carbonates does indicate the types of late-stage diagenetic reactions that may occur in some instances. These include the following:

1. Isotopically light carbon derived from fluids circulating within basalts, probably in the form of methane, may be oxidized during low-temperature alteration of the basalts and become incorporated in secondary carbonate minerals. 
2. Considerable iron and manganese oxides from the basalts may be reduced and liberated to the pore fluids.

3. Pore-fluid, and perhaps solid-phase, sulfates may also be reduced as methane is oxidized.

Despite the fairly closed diagenetic system, the strontium contents of the carbonates from Site 707 are equivalent to values expected for carbonates precipitated from fluids with seawater $\mathrm{Sr} / \mathrm{Ca}$ ratios.

\section{ACKNOWLEDGMENTS}

This research was partially funded by grants from JOIUSSAC (to P. A. Baker and P. K. Swart). This is a contribution from the Stable Isotope Laboratory of the Division of Marine Geology and Geophysics, RSMAS, University of Miami. The Stable Isotope Laboratory was established by NSF grants EAR84-17424 and EAR86-18727. We are also grateful for the efforts of three anonymous reviewers, whose comments helped to improve the manuscript substantially.

\section{REFERENCES}

Anderson, T. F., 1980. Stable-isotope evidence for the origin of secondary carbonate veins in Deep Sea Drilling Project Leg 58 basalts. In Klein, G. deV., Kobayashi, K., et al., Init. Repts. DSDP, 58: Washington (U.S. Govt. Printing Office), 905-911.

Anderson, T. F., and Lawrence, J. R., 1976. Stable isotope investigations of sediments, basalts, and authigenic phases from Leg 35 cores. In Hollister, C. D., Craddock, C., et al., Init. Repts DSDP, 35: Washington (U.S. Govt. Printing Office), 497-505.

Andrews, A. J., 1977. Low-temperature fluid alteration of oceanic Layer 2 basalts, DSDP Leg 37. Can. J. Earth Sci., 14:911-926.

Backman, J., Duncan, R. A., et al., 1988. Proc. ODP, Init. Repts., 115: College Station, TX (Ocean Drilling Program).

Bass, M. N., 1976. Secondary minerals in oceanic basalt, with special reference to Leg 34, Deep Sea Drilling Project. In Yeats, R. S., Hart, S. R., et al., Init. Repts. DSDP, 34: Washington (U.S. Govt. Printing Office), 393-432.

Berner, R. A., 1975. The role of magnesium in the crystal growth of calcite and aragonite from seawater. Geochim. Cosmochim. Acta, 39: 489-504.

Boehlke, J. K., Honnerez, J., and Honnerez-Guerstein, J., 1980. Alteration of basalts from Site 396B, Deep Sea Drilling Project: petrographic and mineralogic studies. Contrib. Mineral. Petrol., 73:341364.

Carothers, W. W., Adami, L. H., and Rosenbauer, R. J., 1988. Experimental oxygen isotope fractionation between siderite-water and phosphoric acid liberated $\mathrm{CO}_{2}$-siderite. Geochim. Cosmochim. Acta, 52: $2445-2450$.

Craig, H., 1987. Comment on "Carbon isotope systematics of a mantle 'hotspot': a comparison of Loihi Seamount and MORB glasses" by R. A. Exley, D. P. Mattey, D. A. Clague, and C. T. Pillinger. Earth Planet. Sci. Lett., 82:384-386.

Dienes, P., 1980. The carbon isotopic composition of diamonds, relationship to shape, color, occurrence and vapour composition. Geochim. Cosmochim. Acta, 44:943-961.

Epstein, S., Buchsbaum, R., Lowenstam, H. A., and Urey, H. C., 1953. Revised carbonate-water isotopic temperature scale. Geol. Soc. Am. Bull., 64:1315-1326.

Exley, R. A., Mattey, D. P., Clague, D. A., and Pillinger, C. T., 1986. Carbon isotope systematics of a mantle "hotspot": a comparison of Loihi Seamount and MORB glasses. Earth Planet. Sci. Lett., 78: 189-199.

Exley, R. A., Mattey, D. P., and Pillinger, C. T., 1987. Low-temperature carbon components in basaltic glasses - reply to comment by $\mathrm{H}$. Craig. Earth Planet. Sci. Lett., 82:387-390.

Gieskes, J. M., 1981. Deep sea drilling interstitial-water studies: implications for chemical alteration of the ocean crust, Layers I and II. In Warme, J. E., Douglas, R. G., and Winterer, E. L. (Eds.), The Deep Sea Drilling Project: A Decade of Progress. Spec. Publ., Soc. Econ. Paleontol. Mineral., 32:149-168.
Hart, S. R., and Staudigel, H., 1978. Ocean crust: age of hydrothermal alteration. Geophys. Res. Lett., 5:202-212.

1979. Ocean crust-sea water interaction: Sites 417 and 418. In Donnelly, T., Francheteau, J., Bryan, W., Robinson, P., Flower, M., Salisbury, M., et al., Init. Repts. DSDP, 51, 52, 53, Pt. 2: Washington (U.S. Govt. Printing Office), 1169-1176.

1983. Age of hydrothermal circulation on the Rio Grande Rise: Deep Sea Drilling Project Site 516. In Barker, P. F., Carlson, R. L., Johnson, D. A., et al., Init. Repts. DSDP, 72: Washington (U.S. Govt. Printing Office), 471-474.

Javoy, M., and Fouillac, A. M., 1979. Stable isotope ratios in Deep Sea Drilling Project Leg 51 basalts. In Donnelly, T., Francheteau, J., Bryan, W., Robinson, P., Flower, M., Salisbury, M., et al., Init. Repts. DSDP, 51, 52, 53, Pt. 2: Washington (U.S. Govt. Printing Office), 1153-1157.

Lawrence, J. R., 1973. Interstitial water studies, Leg 15-stable oxygen and carbon isotope variations in water, carbonates, and silicates from the Venezuela Basin (Site 149) and the Aves Rise (Site 148). In Heezen, B. C., MacGregor, I. D., et al., Init. Repts. DSDP, 20: Washington (U.S. Govt. Printing Office), 891-899.

1980. Temperatures of formation of calcite veins in the basalts from Deep Sea Drilling Project Holes 417A and 417D. In Donnelly, T., Francheteau, J., Bryan, W., Robinson, P., Flower, M., Salisbury, M., et al., Init. Repts. DSDP, 51, 52, 53, Pt. 2: Washington (U.S. Govt. Printing Office), 1183-1184.

Lawrence, J. R., Gieskes, J. M., and Broecker, W. S., 1975. Oxygen isotope and cation composition of DSDP waters and the alteration of Layer II basalts. Earth Planet. Sci. Lett., 27:1-10.

Lawrence, J. R., and Taviani, M., 1988. Extreme hydrogen, oxygen, and carbon isotope anomalies in the pore waters and carbonates of the sediments and basalts from the Norwegian Sea: methane and hydrogen from the mantle? Geochim. Cosmochim. Acta, 52:2077-2084.

McCrea, J. M., 1950. Isotopic chemistry of carbonates and a paleotemperature scale. J. Chem. Phys., 18:849-857.

McKenzie, J., 1980. Stable isotopic study of carbonate minerals from the basalt flows on Suiko Seamount: DSDP Leg 55, Hole 433C. In Jackson, E. D., Koizumi, I., et al., Init. Repts. DSDP, 55: Washington (U.S. Govt. Printing Office), 653-658.

Milliman, J. D., 1974. Marine Carbonates: Berlin-Heidelberg-New York (Springer-Verlag).

Muehlenbachs, K., 1979. The alteration and aging of the basaltic layer of the sea floor: oxygen isotope evidence from DSDP/IPOD Legs 51, 52, and 53. In Donnelly, T., Francheteau, J., Bryan, W., Robinson, P., Flower, M., Salisbury, M., et al., Init. Repts. DSDP, 51, 52, 53, Pt. 2: Washington (U.S. Govt. Printing Office), 1159-1167.

Pineau, F., and Javoy, M., 1983. Carbon isotopes and concentrations in Mid-Ocean Ridge basalts. Earth Planet. Sci. Lett., 62:239-257.

Pineau, F., Javoy, M., Hawkins, J. W., and Craig, H., 1976. Oxygen isotope variations in marginal basins and ocean ridge basalts. Earth Planet. Sci. Lett., 28:299-307.

Poreda, R., Welhan, J., and Craig, H., 1984. Helium isotopes and mantle methane in Icelandic geothermal fluids and volcanic rocks. Eos, 65:1152.

Richardson, S. H., Hart, S. R., and Staudigel, H., 1980. Vein mineral ages of old oceanic crust. J. Geophys. Res., 85B:7195-7200.

Staudigel, H., Frey, F. A., and Hart, S. R., 1979. Incompatible trace-element geochemistry and ${ }^{87 / 86} \mathrm{Sr}$ in basalts and corresponding glasses and palagonites. In Donnelly, T., Francheteau, J., Bryan, W., Robinson, P., Flower, M., Salisbury, M., et al., Init. Repts. DSDP, 51, 52, 53, Pt. 2: Washington (U.S. Govt. Printing Office), 1137-1144.

Staudigel, H., Gillis, K., and Duncan, R., 1986a. K/Ar and Rb/Sr ages of celadonites from the Troodos ophiolite, Cyprus. Geology, 14:7275 .

Staudigel, H., and Hart, S. R., 1985. Dating of ocean crust hydrothermal alteration: strontium isotope ratios from Hole 504B carbonates and a reinterpretation of $\mathrm{Sr}$ isotope data from Deep Sea Drilling Project Sites 105, 332, 417, and 418. In Anderson, R. N., Honnerez, J., Becker, K., et al., Init. Repts. DSDP, 83: Washington (U.S. Govt. Printing Office), 297-303.

Staudigel, H., Hart, S. R., and Richardson, S. H., 1981a. Alteration of the oceanic crust: processes and timing. Earth Planet. Sci. Lett., 52: 311-327. 
Staudigel, H., Kastner, M., and Sturz, A., 1986b. $\delta^{18} \mathrm{O}$ and ${ }^{87} \mathrm{Sr} /{ }^{86} \mathrm{Sr}$ of calcites from the basaltic basement of Deep Sea Drilling Project Site 597: timing and temperature of alteration. In Leinen, M., Rea, D. K., et al., Init. Repts. DSDP, 92: Washington (U.S. Govt. Printing Office), 499-503.

Staudigel, H., Muehlenbachs, K., Richardson, S. H., and Hart, S. R., 1981b. Agents of low temperature ocean crust alteration. Contrib. Mineral. Petrol., 77:150-157.
Welhan, J., Kim., K. and Craig, H., 1981. Hydrocarbons in $21^{\circ} \mathrm{N}$ hydrothermal fluids. Eos, 62:913.

Date of initial receipt: 1 June 1989 Date of acceptance: 5 January 1990 Ms 115B-183 